\title{
EL DERECHO ECLESIÁSTICO DEL ESTADO COLOMBIANO DE 1811 A 1991
}

\author{
POR \\ HERNÁN ALEJANDRO OLANO GARCÍA ${ }^{1}$ \\ Universidad de La Sabana
}

\section{RESUMEN}

El autor presenta las que a su juicio son las siete etapas del derecho eclesiástico del Estado en Colombia, que se desprenden de la parte del ordenamiento jurídico estatal y constitucional, dedicado a la regulación del factor religioso desde una perspectiva civil, presentando un tema controvertido y controversial de la historia constitucional colombiana, cuyo centro principal, en el orden nacional y provincial, fue la condición de nación sujeta a la Iglesia, en la que Dios era y es la fuente de la cual ha emanado la autoridad y la estabilidad de una nación donde el dogma constitucional ha sido el de la religión católica, apostólica y romana, como la única y verdadera religión del Estado.

\section{PALABRAS CLAVE}

Patronato; Derecho Eclesiástico; Iglesia Católica; Monarquía; Ruptura institucional.

\section{THE ECCLESIASTICAL LAW OF THE COLOMBIAN STATE FROM 1811 TO 1991}

\section{ABSTRACT}

The author presents which in your opinion are the seven stages of the ecclesiastical law of the State in Colombia, from the part of the State

${ }^{1}$ Director del Grupo de Investigación en Derecho, Ética e Historia de las Instituciones "Diego de Torres y Moyachoque, Cacique de Turmequé" en la Universidad de La Sabana, Colombia. Investigador Asociado de COLCIENCIAS e Investigador de la Cátedra Garrigues de la Universidad de Navarra. Correo electrónico: hernan.olano@unisabana.edu.co 
and constitutional, legal order dedicated to the regulation of the religious factor from a civil perspective, through a disputed and controversial theme of the Colombian constitutional history, whose main Center, in the national and provincial order it was the condition of nation subject to the Church, in which God was and is the source of which has emanated the authority and stability of a nation where the constitutional dogma has been that of the Catholic, Apostolic and Roman religion as true and only religion of the State.

\section{KEY WORDS}

Ecclesiastical law; monarchy; Catholic Church; Board of Trustees; institutional rupture.

$\begin{array}{ll}\text { Recibido/Received } & 10-09-2013 \\ \text { Aceptado/Accepted } & 12-05-2014\end{array}$

\section{EL DERECHO ECLESIÁSTICO DEL ESTADO COLOMBIANO DE 1811 A 1991}

Durante mucho tiempo se ha creído que lo que hoy conocemos como Derecho Eclesiástico del Estado, también llamado "derecho de libertad religiosa", ${ }^{2}$ era solamente el derecho de la Iglesia (teniéndose por tal solo a la católica) e indistintamente se homologaba con el derecho canónico. Sería en la Universidad de Würzburg, Alemania, durante el siglo XIX cuando se resolvió que en el concepto de derecho eclesiástico no solo cabía el de la Iglesia sino también el del Estado referido a ella. Antes del siglo XVIII, las cuestiones relativas al Derecho Público Eclesiástico se trataban por los canonistas y teólogos a medida que se presentaban y como si fuera en realidad un Derecho Canónico.

Era frecuente la confusión entre Derecho Eclesiástico y el Derecho Canónico; por ejemplo, en 1954, el profesor de la Universidad Nacional de Colombia, Octavio Tobón R., ${ }^{3}$ decía que:

2 Saldaña, Javier. 1999. "Derecho y principio de libertad religiosa. Un breve análisis de la actitud promotora del Estado frente al hecho religioso". Boletín Mexicano de Derecho Comparado, 95: 588.

${ }^{3}$ Tobón R., Octavio. 1954. Compendio de Derecho Público Eclesiástico. 9 Bogotá: Temis. 
"Derecho eclesiástico es el conjunto de leyes promulgadas por Dios o por la autoridad eclesiástica para la constitución y régimen de la Iglesia.

Se denomina también divino por razón de la autoridad que lo constituye; religioso por el fin; sagrado en razón de la materia, de la autoridad y del fin; y pontificio en razón a la primera autoridad humana que lo establece.

El nombre más común es el de canónico; se deriva del griego "canon" que traduce regla o medida. Así se pudieron, por lo tanto, llamar todas las leyes eclesiásticas y civiles; pero el uso ha consagrado esta denominación para las solas leyes eclesiásticas universales (pero no para las leyes de los obispos las cuales son particulares)."

El Derecho Eclesiástico del Estado, es una parte del ordenamiento jurídico estatal dedicado a la regulación del factor religioso desde una perspectiva civil, mientras que el Derecho Canónico es el Derecho de la Iglesia Católica, razón por la cual Prieto Martínez ${ }^{4}$ señala que su historia académica es más bien reciente y que "su objeto propio es el estudio de la normativa estatal en materia religiosa, es decir el modo cómo el Estado regula el hecho religioso en su dimensión social y plantea sus relaciones con las distintas confesiones religiosas, entre ellas con la Iglesia Católica".

Y agrega:

"Cabe sin embargo un enfoque distinto, que consiste en examinar las relaciones externas institucionales de la Iglesia desde ella misma, desde su propio ordenamiento (el Derecho Canónico). Con otras palabras, esta perspectiva busca identificar y exponer los principios y reglas de justicia que, desde el punto de vista del ordenamiento jurídico de la Iglesia Católica, regulan sus relaciones con otras sociedades u organismos jurídicamente organizados.

El punto de partida ha de ser la adecuada distinción entre la Iglesia y las distintas formas de comunidad política: solamente la distinción preliminar de sujetos permite plantear la existencia de una relación jurídica entre la Iglesia y otros entes, que son distintos de ella misma."

4 Prieto, Vicente. 2005. Relaciones Iglesia-Estado. La perspectiva del Derecho Canónico. 9, Salamanca: Publicaciones de la Universidad Pontificia de Salamanca. 
Uribe y Lastra, ${ }^{5}$ dicen que la expresión Derecho Eclesiástico del Estado, "usada tradicionalmente como sinónimo de Derecho Canónico, es decir para indicar un sistema de Derecho que se proclama independiente, en el sentido de que el Estado no podrá por propia iniciativa emanar normas jurídicas en materia eclesiástica o religiosa, ha llegado a usarse para indicar, la parte del Derecho del Estado que regula el fenómeno social religioso."

Saldaña ${ }^{6}$ dice que el Derecho Eclesiástico es "la distinción entre lo que se reconoce en la doctrina como principio de libertad religiosa y el derecho de libertad religiosa. El primero fija los límites del segundo y define la identidad del Estado ante el fenómeno religioso, entendido éste como derecho fundamental de la persona o de la sociedad." Esto es parte del reconocimiento a la Iglesia católica como institución determinante de la cohesión social en la América hispana.

Uribe y Lastra, ${ }^{7}$ presentan su propia definición al decir que "el Derecho del Estado Colombiano en materia religiosa (Derecho Eclesiástico del Estado Colombiano) es el conjunto de normas del ordenamiento jurídico del Estado Colombiano que regulan el fenómeno religioso, en cuanto hecho social, sin entrar a regular lo que sólo pertenece a la autonomía de cada confesión religiosa."

También puede concebirse como una rama autónoma del Derecho dentro del Estado, constituida por la parte de éste dedicada a la materia eclesiástica, ${ }^{8}$ mientras que otros ${ }^{9}$ lo entienden como el que hace referencia a la disciplina que estudia el conjunto de normas del ordenamiento jurídico del Estado que regula materias que éste considera eventos con una finalidad religiosa.

También se ha dicho ${ }^{10}$ que esta parte del Derecho del Estado se denomina "ius publicum externum", por estar contenido en múltiples documentos, en relación a las transformaciones políticas y a las tendencias culturales de épocas recientes, especialmente en aquellos emanados de los pontífices del siglo XX, y por estar basado también en

${ }^{5}$ Uribe Blanco, Mauricio y Lastra Jiménez, Álvaro. 1990. Derecho Eclesiástico del Estado Colombiano. Fundamentos. 12 Bogotá: Universidad de La Sabana.

${ }^{6}$ Saldaña, Javier. 1999: p. 588.

${ }^{7}$ Uribe Blanco, Mauricio y Lastra Jiménez, Álvaro. 1990: p. 17.

${ }^{8}$ Vásquez García-Peñuela, José María. 1994. "El objeto del Derecho Eclesiástico y las Confesiones Religiosas". Ius Canonicum, 67: 280.

${ }^{9}$ Saldaña, Javier. 2004. "Derecho y Religión”. ARS IURIS, 103: 457.

10 Del Giudice, Vincenzo. 1955. Nociones de Derecho Canónico. Traducción y notas de Pedro Lombardía. 333, Pamplona: Publicaciones del Estudio General de Navarra. 
el Derecho divino positivo y en el orden natural de las cosas, ya que tanto la Iglesia como el Estado son soberanas en su propio campo (utraque est in suo genere maxima) y tienen la razón de ser y la determinación de sus respectivas competencias en una colaboración que les resulte armónica para el cumplimiento de sus fines.

Pedro Lombardía en su Derecho Eclesiástico del Estado Español, ${ }^{11}$ dice que la denominación Derecho Eclesiástico, se debe reservar "no para las iglesias, sino para el del Estado relativo a la Iglesia o a las Iglesias. Este nuevo sentido, significa un desplazamiento de la significación del adjetivo eclesiástico aplicado al Derecho: de una calificación en razón de la fuente (Derecho Eclesiástico $=$ Derecho dictado por la Iglesia), se pasa a una calificación en razón de la materia (Derecho Eclesiástico = relativo a la Iglesia o a las iglesias); de tal suerte que actualmente cabe distinguir en materia religiosa un Derecho Canónico (procedente de fuentes eclesiásticas, concretamente de la Iglesia Católica) y un Derecho Eclesiástico (dictado por los órganos competentes del Estado)."

Es por eso que hoy en día podemos afirmar que tanto el Derecho Canónico, como el Derecho Eclesiástico del Estado, gozan de autonomía científica. Y esa presunta autonomía científica del discurso académico sobre el Derecho Eclesiástico Colombiano, depende "de que sea posible una sistematización científica unitaria y complexita, tanto por la significación del objeto cuanto por la posibilidad de que las diversas regulaciones que el orden jurídico otorga al tema religioso obedezcan a unos principios informadores, cuya indagación debe constituir cometido de esta rama científica". ${ }^{12}$

Lógicamente antes de que en 1991 se reformase la Constitución de 1886, Uribe y Lastra $^{13}$ decían que "la denominación Derecho Eclesiástico del Estado Colombiano que se utiliza es convencional, ciertamente puede inducir a confusión y no se ajusta con precisión a su contenido".

Y agregan:

"En efecto, respetando y aceptando la tradición de la disciplina que impuso esa terminología, como se dijo, debe aclararse que, a pesar del adjetivo eclesiástico, dentro de su

11 Lombardía, Pedro. 1980. Derecho Eclesiástico del Estado Español. 25, Pamplona: EUNSA.

12 Uribe Blanco, Mauricio y Lastra Jiménez, Álvaro. 1990: p. 19.

13 Uribe Blanco, Mauricio y Lastra Jiménez, Álvaro. 1990: p. 15. 
ámbito, según las nuevas perspectivas del Derecho Eclesiástico moderno, habría que incluir:

1. Todo el sector del ordenamiento jurídico del Estado que regula las manifestaciones sociales del fenómeno religioso, y no sólo de la confesión religiosa católica; o sea, también las confesiones religiosas cristianas (iglesias) y demás grupos religiosos.

2. Tanto desde la perspectiva institucional (posición jurídica de la Iglesia Católica como de otras confesiones y grupos religiosos globalmente considerados en el ordenamiento del Estado); como desde la perspectiva individual (libertad personal del ciudadano para adoptar posiciones ante el tema religioso que el ordenamiento debe regular."

Por tanto, dentro del Derecho Eclesiástico del Estado, se hace referencia al conjunto de normas del ordenamiento jurídico estatal que regulan la dimensión social del factor religioso como hecho social. ${ }^{14}$

\section{ETAPAS DEL DERECHO ECLESIÁSTICO DEL ESTADO COLOMBIANO:}

Prehispánica y Precolombina:

Antes del régimen de Patronato, podemos encontrar en esta periodización, las disposiciones no escritas de los indígenas acerca de sus deidades y la relación entre ellas y sus súbditos. Por ejemplo, en el Altiplano Cundiboyacense, ${ }^{15}$ las disposiciones religiosas se referían al origen del hombre, las normas de su conducta, la protección en la vida y las esperanzas después de la muerte; creencias y concepciones tan elevadas y formales como su culto.

Bochica o Nemqueteba, el patrono universal de los chibchas, simbolizaba las relaciones entre el sol, padre de la luz, y el agua, madre de los hombres y dejó el poder espiritual en manos del cacique Sogamoso, quien expedía las disposiciones para el universo; lo mismo hicieron Nompanim, el gran legislador y Nemequene quien expidió su propio código, con disposiciones que por algún contenido religioso para la región chibcha, nos llevan a atrevernos a decir que ya aquí antes de 1503, año de llegada de los españoles a nuestras costas, ya había una especie de Derecho Eclesiástico Chibcha, lógicamente de carácter mítico

14 Lombardía, Pedro. 1983. Derecho Eclesiástico del Estado español. Segunda edición, 28, Pamplona: Eunsa.

15 García, Julio César. 1972. Los Primitivos. 14 ${ }^{a}$ edición. Bogotá: Editorial Voluntad, p. 199. 
y recogido en la tradición oral, pues no conocieron la escritura hasta la llegada de los españoles.

Pero, en cuanto al régimen Precolombino, que propiamente alimenta esta etapa en América, ya en la Península, algunas bulas emitidas los años 1478, 1482 y 1487 habían reconocido a los monarcas españoles el privilegio de nombrar Inquisidor General con la competencia de ser juez de apelaciones en Castilla. Esto significaba que las discrepancias entre la jurisdicción eclesiástica ordinaria e inquisitorial se resolverían por el Inquisidor General.

La monarquía también contribuyó al fortalecimiento de las facultades y competencias del Santo Oficio cuando en 1501, Fernando el Católico concedió prioridad a la jurisdicción inquisitorial sobre las otras, y en 1503 extendió su jurisdicción a todas las causas civiles o criminales que afectasen a los oficiales del Santo Oficio. Luego, en 1505 le advirtió a los Justicias de Cataluña que la jurisdicción del Santo Oficio «es superior a la de los fueros». Así, los conflictos y excesos llevaron a Carlos $V$ a suprimir la jurisdicción temporal del Santo Oficio, que Felipe, como regente, volvió a reconocer en 1535 y su padre a ratificar en 1545.

Sin embargo, el régimen de patronato no es que fuera propiamente nacional, pues por ejemplo, el de las islas Canarias no se menciona ${ }^{16}$ en los textos trascendentales sobre el tema en España y en América. $Y$ es que las normas del Derecho Estatal Indiano no tienen más fuente que la autoridad de la Corona. ${ }^{17}$

\section{Patronato.}

Aparte de la protección a la Iglesia, que competía a todo príncipe cristiano, Perasa de Ayala ${ }^{18}$ señala que la legislación castellana invoca desde el siglo XIII "una especie de patronato al que denomina «mayoría e honra», obtenido por los reyes en razón de haber ganado «las tierras a los moros» y por la implantación del Cristianismo en ellas, transformando las mezquitas en iglesias (ley XVIII, título V de la Partida Primera), en donde expresa que el derecho a presentar para la provisión de determinados beneficios correspondía a los monarcas «por respecto de la conquista" y que era costumbre tolerada por la Santa Sede (de tiempo inmemorial y aun por virtud de ellas dadas algunas sentencias en Corte de Roma), ley III, titulo III del libro I de la Nueva Recopilación).

${ }^{16}$ Perasa de Ayala, Álvaro. El Real Patronato de Canarias. 1960: p.8.

17 De la Hera, Alberto: 1992. El gobierno de la Iglesia indiana, en: Sánchez Bella, Ismael, De la Hera Alberto, Díaz Remetería, Carlos. Historia del Derecho Indiano. Madrid, Mapfre, p. 258

${ }^{18}$ Perasa de Ayala. Álvaro. 1960: p 9. 
En disposiciones pontificias encontramos antecedentes más directos. Desde la época del papa Alejandro II se expiden a favor de los monarcas españoles bulas por las que se les confiere la facultad de repartir iglesias, entre las cuales se halla la despachada por Urbano II, donde se concede a los reyes las iglesias y capillas de las tierras tomadas a los sarracenos. Eugenio IV en 23 de julio de 1436, reconoce a Juan II de Castilla el derecho a disponer de varias -dignidades y otros bienes eclesiásticos, "así como el de patronato en las diversas iglesias y capillas» en atención a qua dicho rey había invocado la vigencia de la mentada bula de Urbano II, que disponía la distinción a los Reyes «como celadores de la Fe Católica». Además, Eugenio IV, en el propio documento, reserva para la Corona, a perpetuidad, el derecho de patronato en todas y coda una de las iglesias de los territorios adquiridos de los musulmanes $y$ en las que en adelante se obtengan por transformación de las mezquitas en sitios de alabanza al $<<$ Divino Nombre >>, o que los soberanos y sus sucesores en los reinos de Castilla y de León fundasen y dotaran de bienes. También se les otorgaba el privilegio de presentar a los ordinarios de los lugares a personas idóneas pares las mismas iglesias cuantas veces vacaren. El texto de esta bula fue transcrito y mandado observar de nuevo por Inocencio VIII, el 14 de mayo de 1486, a petición de los Reyes Católicos.

Con razón se ha dicho que los reyes eran una especie de vicarios papales, algo que posteriormente asumiría el gobierno civil durante el siglo XIX al reconocimiento de la independencia y, como consecuencia de esto, desde el mismo siglo XVI se plantean serios problemas en la provisión de sedes vacantes, consagración de obispos etc., par la tardanza en llegar de los documentos pontificios.

En América, esta etapa del Derecho Eclesiástico del Estado va prácticamente desde las bulas Alejandrinas de 1493, por las que la Santa Sede concedía la administración de las tierras recién descubiertas a los reyes católicos, don Fernando y doña Isabel, quienes se comprometían a propagar la fe en las tierras descubiertas. Ese sistema, conocido como el de Regio Patronato Indiano abarca desde fines del siglo XV hasta la mitad del siglo XIX dentro de la república neogranadina.

"El Derecho Colombiano sobre materia religiosa de estos siglos es Derecho Canónico, controlado por la Monarquía por medio de la institución del pase regio y matizado por las normas dictadas por los reyes en el ejercicio de sus poderes mayestáticos circa sacra.

La fisonomía de las fuentes del Derecho Eclesiástico de este período es unilateral: disposiciones pontificias o reales. 
Indudablemente, la forma jurídica de tratar el factor religioso fue confesionalmente católica e intolerante con respecto a otras confesiones". ${ }^{19}$

En atención a la responsabilidad que asumían los monarcas españoles, Alejandro VI expidió la bula eximia devotionis en 1501, en la que les reconoce el derecho a recibir los diezmos eclesiásticos, a condición de que financiasen los gastos del culto, y Julio II, mediante la Universales Ecclesiae de 1508, les otorgó la facultad de presentar candidatos idóneos para dirigir las Iglesias metropolitanas, las catedrales, las colegiatas, las parroquias, proponer la erección de diócesis, catedrales, curatos, monasterios, etc.

Según Jorge Adame Goddard, ${ }^{20}$ "esta relación de los monarcas españoles con la propagación de la fe dio una configuración peculiar al Imperio Español en Indias, que ha sido calificado acertadamente como un Imperio-Misión. El poder político en Indias se fundó en la donación papal y en la obligación de difundir la fe. El poder político se extendió como un instrumento al servicio de la fe, y el servicio de la fe se extendió como justificación de la expansión del poder político".

Dentro del mismo período del Regio Patronato, algunos autores sostienen que hubo dos etapas nacidas del cambio de dinastía en la Casa Real española; por ejemplo, Adame Goddard, ya citado dice que "la primera etapa corresponde a los monarcas de la Casa de Austria, y termina con la muerte del último de ellos, Carlos II, el año de 1700. La segunda, corresponde a la dinastía borbónica que se establece definitivamente al triunfar Felipe $V$ en la guerra de sucesión de 1713".

Agrega Adame Goddard que, los inconvenientes se dieron porque:

"durante la primera etapa, los monarcas ejercen el Regio Patronato en concordancia con la obra evangelizadora de la Iglesia, y si bien son notables las intromisiones del poder político en asuntos de orden espiritual o eclesiástico, no hay una relación de conflicto permanente entre el monarca y la Iglesia.

Con el advenimiento de los borbones, la relación cambia. Entonces los monarcas aducen el derecho de Patronato como medio de dominación o control sobre la Iglesia. Es la doctrina del "regalismo" que pretende la supeditación de la Iglesia al monarca ilustrado. Como manifestaciones claras de ese nuevo modo de

${ }^{19}$ Uribe Blanco, Mauricio y Lastra Jiménez, Álvaro. 1990: p. 22.

20 Adame Goddard, Jorge. 1992. "Las Reformas Constitucionales en materia de libertad religiosa". Ars luris, 7: 1 - 3. 
entender el patronato puede citarse la expulsión de los jesuitas de todo el Imperio Español, ordenada por Carlos III, el año de 1767".

Por su parte, Juan Antonio Eguren, S.J., ${ }^{21}$ señalaba de este período que el gobierno republicano desde sus albores se consideró heredero legítimo del Patronato regio y así, "a impulsos de unos pocos eclesiásticos, se puso a ejercer sus atribuciones privilegiadas. Pero siempre flotaba la duda, duda que se procuraba desvanecer con la sugerencia de acreditar una misión diplomática ante el Vaticano.

"Ya a principios de diciembre de 1810, la primera Junta Suprema organizada en Socorro, Santander del Sur, se atribuyó los derechos del Patronato eclesiástico y llegó a decretar la erección de la sede episcopal del Socorro y nombrar para Obispo al doctor Andrés Rosillo, Canónigo Magistral de la Catedral Bogotana, Eclesiástico distinguido por su cultura, miembro principal de la Junta y partidario decidido de sus tendencias cismáticas".

De las Constituciones Provinciales:

Precisamente el primer documento constitucional que fuera expedido en Colombia, la Carta de Cundinamarca de 1811, donde el soberano constituyente era el pueblo católico, se dedicó su título segundo $^{22}$ al Derecho eclesiástico del Estado, así: ${ }^{23}$

Título II. De la religión

Artículo 1.- La Religión Católica, Apostólica, Romana es la Religión de este Estado.

Artículo 2.- No se permitirá otro culto público ni privado, y ella será la única que podrá subsistir a expensas de las contribuciones de la provincia y caudales destinados a este efecto, conforme a las leyes que en materia gobiernan.

Artículo 3.- A fin de evitar el cisma y sus funestas consecuencias, se encargará a quien corresponda, que a la mayor brevedad posible y con preferencia a cualquiera negociación diplomática, se trate de entablar correspondencia directa con la

${ }^{21}$ Eguren, Juan Antonio, S.J. 1974. Derecho Concordatario Colombiano. 166, Bogotá: Librería Stella.

${ }_{22}$ Pombo, Manuel Antonio y Guerra, José Joaquín. 1986. Constituciones de Colombia. Tomo I, 4 ed. Bogotá: Biblioteca del Banco Popular. pp. 300 - 301

${ }^{23}$ Olano García, Hernán Alejandro. 2006. La Constitución Monárquica de Cundinamarca. Bogotá: Colección Portable, Academia Colombiana de Jurisprudencia. 
Silla Apostólica, con el objeto de negociar un Concordato y la continuación del patronato que el Gobierno tiene sobre las iglesias de estos dominios.

Artículo 4.- La base de este Concordato deberá ser la facilidad $y$ pronto despacho de los negocios $y$ vacantes eclesiásticos, o por medio de un legado a latere, con continua residencia en esta capital, o mejor, por el de un Sínodo permanente; autorizado uno u otro con todo el lleno de las facultades pontificias.

Artículo 5.- La autoridad civil no se entrometerá a juzgar en materia de culto, ni otras puramente eclesiásticas; no prestará mano fuerte para estos efectos, ni tampoco exigirá que el eclesiástico emplee la excomunión ni demás armas eclesiásticas en materias civiles; pero no por esto abdica el derecho de protección que tiene sobre los eclesiásticos y demás ciudadanos, el que ejercerá en los recursos de fuerza en sus casos.

Artículo 6.- Tampoco permitirá que la autoridad eclesiástica conozca en otras materias, sino en las de culto y puramente eclesiásticas; ni que para sostener sus providencias use más armas ni coacción que la de la Iglesia, sin entrometerse ni impedir las funciones civiles.

En contraposición a los Cundinamarqueses, el Congreso de las Provincias Unidas de la Nueva Granada dictó su Constitución ${ }^{24}$ el 27 de noviembre de 1811 , que sobre el particular disponía que: ${ }^{25}$

Artículo 4.- En todas y cada una de las provincias unidas de la Nueva Granada se conservará la santa religión Católica, Apostólica, Romana, en toda su pureza e integridad.

Artículo 17.- Al mismo fin no perderán momento en disciplinarse formando compañías y cuerpos según lo permitan sus poblaciones, ejercitándolos uno o dos días en la semana, pero principalmente los festivos después de la asistencia a la misa de sus parroquias, como una ocupación que además de su utilidad

24

http://www.cervantesvirtual.com/servlet/SirveObras/8914517321121492953245 7/p0000001.htm\#l 0, consultada el $1^{\circ}$ de agosto de 2013.

${ }^{25}$ Olano García, Hernán Alejandro. 2010. El Acta de Confederación de las Provincias Unidas de la Nueva Granada. En: Vidal Perdomo, Jaime (Compilador). (2010). Historia constitucional de Colombia - Siglo XIX. Tomo I. Bogotá, D. C., Ediciones de la Academia Colombiana de Jurisprudencia, pp. 29-42. 
para la Patria, y de distraerlos de otras, tal vez no igualmente sanas, es hoy la que puede considerarse como más apta a los ojos de Dios por deber emplearse sus servicios en defensa de la misma Patria, de sus más caros derechos, y de la religión de nuestros padres amenazada; $y$ así deberán hacérselo entender todos los párrocos excitados por la autoridad civil, si no cumplieren de su propio movimiento, lo que no es de esperarse, con este religioso deber.

Artículo 24.- No por esto se despojará ni se hará la menor vejación o agravio a las tribus errantes, o naciones de indios bárbaros que se hallen situadas o establecidas dentro de dichos territorios; antes bien se las respetará como legítimos y antiguos propietarios, proporcionándoles el beneficio de la civilización y religión por medio del comercio y por todas aquellas vías suaves que aconseja la razón y dicta la caridad cristiana, y que sólo son propias de un pueblo civilizado y culto; a menos que sus hostilidades nos obliguen a otra cosa.

Artículo 26.- Pero, si dentro de los límites conocidos de las provincias, o entre provincia y provincia, hubiera naciones de esta clase, ya establecidas que hoy pudieran hacer cómodamente parte de esta unión o de las mismas provincias, principalmente cuando ya no las aterra un tributo ignominioso, ni un gobierno bárbaro $y$ despótico, como el que ha oprimido a sus hermanos, por trescientos años, se las convidará y se las atraerá por los medios más suaves, cuales son regularmente los del trato y el comercio, a asociarse con nosotros, y sin que sea un obstáculo su religión, que algún día cederá tal vez el lugar a la verdadera, convencidos con las luces de la razón y el evangelio que hoy no pueden tener.

Posteriormente, Tunja ${ }^{26}$ proclamaría la segunda Constitución provincial de nuestra actual patria, incluyendo las siguientes normas de Derecho Eclesiástico del Estado; sin embargo, otro ejemplo muy similar a la tunjana, se encuentra en la Carta de Antioquia, donde podemos leer:

Artículo 2.- Los deberes del ciudadano consisten en la pureza de la Religión y de las costumbres y en el amor de sus semejantes, derivándose principalmente de los dos principios siguientes, inspirados por la naturaleza, sancionados por la ley $y$ consagrados por la Religión: No hagas a otro lo que no quieres se

${ }^{26}$ Olano García, Hernán Alejandro. Bicentenario de la Constitución de Tunja. En: Zambrano Cetina, William (Compilador). (2011). Las Constituciones de la Primera República. Memorias del Coloquio Conmemorativo del Bicentenario de la Constitución de Tunja. Ediciones de la Academia Colombiana de Jurisprudencia, Bogotá, D.C. 
haga contigo. Haz constantemente a los demás el bien que quisieras recibir de ellos.

Artículo 11.- Un frecuente recurso a los principios fundamentales de la Constitución, y un amor constante a la religión, piedad, justicia, industria y frugalidad son absolutamente necesarios para conservar las ventajas de la libertad.

En el Título II, encontramos la siguiente disposición:

Artículo 7.- La religión Católica, Apostólica, la única divina y verdadera, que sirviendo de freno a las pasiones hace a los magistrados obrar en justicia y a los súbditos obedecer a la ley, es la Religión de la Provincia de Antioquia; ella será conservada en toda su pureza e integridad, y protegida por el Gobierno.

Y en el XI, dedicado a la instrucción pública se dispone:

Artículo 3.- Habrá igualmente un colegio y universidad en que se enseñe a los jóvenes de toda la provincia la gramática, la filosofía en todos sus ramos, la religión, la moral, el derecho patrio con el público, y político de las naciones. La Legislatura excogitará los fondos para el establecimiento, cuidando de que se funden a la mayor brevedad posible las cátedras más necesarias.

Bien elocuentes fueron también los preámbulos, en los que el pueblo como soberano adjudicó a Dios el destino de la nación y se le encomendaron los destinos nacionales a la religión Católica, Apostólica y Romana, única y verdadera, como se lee en varios textos constitucionales.

Ya para 1810, la Iglesia católica contaba con la Arquidiócesis de Bogotá y con las cinco diócesis de Popayán, Antioquia, Cartagena, Panamá y Santa Marta, que fue la primera en ser creada en el siglo XVI.

En cuanto a la religión, la nueva Constitución de Cundinamarca de 1812 fue todavía más Católica que la anterior, erigiéndose el Estado en el protector de la única religión permitida, como resulta del Título I, que se cita a continuación:

Artículo $1^{\circ}$. La Religión Católica, Apostólica, Romana es la única Religión de este Estado.

$2^{\circ}$. El Estado de Cundinamarca protesta permanecer siempre en esta Santa Religión, fuera de la cual no hay esperanza de salud eterna; confiesa y promete defender con todo su poder las 
infalibilidades verdaderas que ella enseña, dictadas por Dios; detesta y anatematiza todas las herejías que ella condena $y$ reprueba.

$3^{a}$. Reconoce al Sumo Pontífice de Roma por Vicario de Jesucristo y Suprema Cabeza visible de la Iglesia universal. privado.

4a. En este Estado no se permite otro culto público ni

5. A la mayor posible brevedad y con preferencia a toda otra negociación, se tratará de establecer correspondencia directa con la Silla apostólica y negociar con ella un concordato y la continuación del patronato que el Gobierno ha tenido sobre las iglesias de sus dominios. La base de este Concordato deberá ser la facilidad y pronto despacho de los negocios y las vacantes eclesiásticas.

$6^{a}$. La potestad civil no se entrometerá en materias eclesiásticas, ni la eclesiástica se mezclará en materias civiles; pero se auxiliarán mutuamente en sus casos, conforme a los sagrados cánones y a las leyes.

El 30 de diciembre de 1811, Antioquia consagró como su patrona a la Inmaculada Concepción, bajo cuyo amparo, el 1 de enero de 1812 se dio inicio a la reunión del Serenísimo Congreso Constituyente y Electoral de Antioquia, que tendría como misión expedir su Constitución, ${ }^{27}$ se expediría con el patrocinio del "Autor Supremo de la Naturaleza» y, comenzaba con estos dos primeros artículos:

1. El pueblo de la Provincia de Antioquia y sus representantes reconocen y profesan la Religión Católica, Apostólica, Romana como la única verdadera: ella será la Religión del Estado.

2. Considerando que el olvido de los sagrados e imprescriptibles derechos del hombre y de las obligaciones del ciudadano es la causa primaria y el origen del despotismo, de la tiranía y de la corrupción de los gobiernos, y que por este mismo olvido e ignorancia los pueblos sufren por muchos siglos la esclavitud y las cadenas, o cometen mil excesos contrarios al orden y a la institución de las sociedades; nosotros los representantes del bueno y virtuoso pueblo del Estado de

27 Olano García, Hernán Alejandro. La Constitución de Antioquia de 1812. 2012. Bogotá: Ediciones de la Academia Colombiana de Jurisprudencia, Colección Portable. 
Antioquia, proclamamos a la faz de las naciones, y bajo los auspicios del Todopoderoso, los siguientes derechos del hombre $y$ los deberes del ciudadano, para que indeleblemente permanezcan grabados en todos los corazones.

La Constitución, además le asignaba a la legislatura por objeto primero y sublime, mantener por medio de leyes sabias la Sacra Religión Católica, Apostólica, Romana en toda su pureza e integridad; hacer las leyes en todos los ramos de la legislación; promover y conservar las virtudes religiosas, morales y políticas, las costumbres públicas y privadas, la ilustración, la agricultura, la industria y el trabajo, pues la legislatura sólo debería nacer para ser fuente de la felicidad del Estado. También el Título Noveno, es muy similar al incluido en la Constitución de Tunja de 1811, así como a alguna redacción similar que también se encontraba en la Constitución de Cundinamarca de 1811; se refiere en 4 artículos a la Instrucción pública, que son también similares a los que dos días y a ocho mil kilómetros de distancia, antes aparecieron el 19 de marzo de 1812 en la Constitución de Cádiz:

"Artículo 1.- Habrá en todas las parroquias de la provincia escuelas de primeras letras, en que se enseñen gratuitamente a los niños de cualquiera clase y condición que sean, a leer, escribir, las primeras bases de la religión, los derechos del hombre y los deberes del ciudadano, con los principios de la aritmética y la geometría. Dichas escuelas se irán estableciendo luego que lo permitan las circunstancias, quedando a cargo de la Legislatura el buscar medios para que se doten sin gravamen de las actuales rentas públicas.

Artículo 2.- Habrá igualmente un Colegio y Universidad en que se enseñe a los jóvenes de toda la provincia la gramática, la filosofía en todos sus ramos, la religión, la moral, el derecho patrio con el público y político de las naciones. La Legislatura excogitará los fondos para el establecimiento, cuidando de que se funden, a la mayor brevedad posible, las cátedras más necesarias.

Artículo 3.- Los Poderes Legislativo y Ejecutivo formarán con la mayor actividad la erección de sociedades públicas y privadas, que promuevan la agricultura, la minería, las ciencias, el comercio y la industria, perfeccionando los inventos que se conozcan e introduciendo otros nuevos que puedan ser útiles al país. Para lo cual todos los años destinará la Legislatura una cantidad moderada que se distribuya en premios a los que juzgue que lo merecen. 
Artículo 4.- Una de las primeras obligaciones de la Legislatura y magistrados que haya en los futuros períodos de esta República, será cuidar que la buena educación, las ciencias y las virtudes públicas y religiosas se difundan generalmente por todas las clases del pueblo, y para que sus individuos sean benéficos, industriosos y frugales; para que todos los ciudadanos conozcan sus derechos, amen la patria con la libertad, y defiendan hasta la muerte los inmensos bienes que con ella han adquirido."

Mientras que el último de los antecedentes se produjo el 14 de junio de 1812 con la Constitución del Estado de Cartagena de Indias, de características similares a las de otros documentos estudiados, que fijaba el principio y fin del Estado, como era el de "asegurar la existencia del cuerpo político, protegerlo y proporcionar a los individuos que le componen el poder gozar en paz y seguridad de sus derechos naturales y de los bienes de la vida", darse su gobierno y garantizarse su seguridad y felicidad, bajo la figura del Pacto Social, que garantice, además, el bien común en la provincia y por fuera de los cuales no habría gobierno legítimo, según lo expresa dicha Carta, bajo los auspicios y reconocimiento del "Supremo Legislador y Árbitro del universo", bajo cuya presidencia está también el curso de las vicisitudes humanas, quien

... se ha dignado devolvernos el derecho de existir, mantenernos y gobernarnos por nosotros mismos, disuelto el cuerpo político en que estábamos adsorbidos y anonadados, $y$ constituidos en aptitud, oportunidad y aun precisión de asociarnos por pacto fundamental, solemne y explícito, y de formar una Constitución de Gobierno civil para nosotros y nuestra posteridad.

Esta Constitución hizo alusión a las ideas de la llustración que soplaron con fuerza en el Nuevo Mundo. Firmada por 34 delegatarios de las cinco provincias que integraban el Estado, y es un ejemplo de dignidad y voluntad libertaria, empezado por dejar claro que el de Cartagena era un "Estado libre, soberano e independiente, absuelto de toda sumisión, vasallaje, obediencia", y llama la atención la invocación celestial de Dios como "Supremo Legislador y Árbitro del Universo", bajo cuya Providencia se enmarca "el derecho a existir, mantenernos y gobernarnos por nosotros mismos", que antecede el contenido de los títulos constitucionales. ${ }^{28}$

Pasado el período de la Patria Boba, y luego del régimen del terror, pudo culminarse la independencia con la definitiva batalla del Puente de Boyacá, donde míticamente se selló la libertad granadina (aunque

${ }^{28}$ Olano García, Hernán Alejandro. 2013. La Constitución del Estado de Cartagena de Indias. Bogotá: Colección Portable de la Academia Colombiana de Jurisprudencia. 
jurídicamente fueron otros los hechos que propiciaron la independencia) y se constituyó una floreciente nación con el nombre de Colombia.

1819 a 1853.

La etapa propuesta corresponde al período en el cual se buscó realizar un acercamiento de la naciente República de Colombia y de la República Neogranadina a la Santa Sede, para lo cual se destacó un Comisionado, el cual en principio fue hostigado por el Embajador español y obligado a retirarse a Florencia, hasta que finalmente obtuvo el reconocimiento parcial de la soberanía estatal.

En los apartes del texto de las Constituciones expedidas durante estos años, que se incluyen más adelante, veremos cómo se fue dando la evolución en el tema, que incluyó el que en 1821 el Congreso aboliera el Tribunal de la Inquisición, que había sido restablecido durante el "Régimen del Terror" por el brigadier Pablo Morillo, así como una ley de 1824 que consagraba el Patronato.

En septiembre de 1819, el Libertador Simón Bolívar se encaminó a la ciudad de Santo Tomás de Angostura, donde se hallaba reunido el Congreso de Venezuela, bajo cuyo patrocinio se había liberado al Virreinato. Allí fue expedida nuestra primera Ley Fundamental el 17 de diciembre, que sobre el tema religioso únicamente expresó:

Artículo 13.- La República de Colombia será solemnemente proclamada en los Pueblos y en los Ejércitos, con fiestas y regocijos públicos, verificándose en esta capital el 25 del corriente diciembre en celebridad del nacimiento del Salvador del Mundo, bajo cuyo patrocinio se ha logrado esta deseada reunión, por la cual se regenera el Estado.

Luego del receso obligatorio del Congreso, y vuelto éste a reunirse en 1821, fue expedida la Ley Fundamental de la Unión de los Pueblos de Colombia el 18 de julio de ese año "En el nombre y bajo los auspicios del Ser Supremo", y posteriormente, el 30 de agosto, "En el nombre de Dios, Autor y Legislador del Universo", el Congreso de Cúcuta expediría nuestra primera Constitución Nacional, en cuya Declaración final dirigida a los habitantes de Colombia, podemos leer:

"Tal ha sido el plano sobre que se ha levantado a la Constitución de Colombia. Vuestros representantes sólo han puesto una confianza ilimitada en las leyes; porque ellas son las que aseguran la equidad entre todos y cada uno; y son también el apoyo de la dignidad del colombiano, fuente de la libertad, el alma y el consejo de la República. Pero lo que vuestros representantes 
han tenido siempre a la vista, y lo que ha sido el objeto de sus más serias meditaciones, es que las mismas leyes fuesen enteramente conformes con las máximas y los dogmas de la Religión Católica Apostólica y Romana, que todos profesamos y nos gloriamos de profesar: ella ha sido la religión de nuestros padres, y es y será la Religión del Estado; sus ministros son los únicos que están en el libre ejercicio de sus funciones, y el Gobierno autoriza las contribuciones necesarias para el Culto Sagrado."

Declarada sin efecto la Constitución de 1821 y fracasado el proyecto de reformarla en la Convención de Ocaña de 1828, el Libertador asumiría los poderes dictatoriales de la República y en fecha 25 de agosto de 1828, expediría el célebre "Decreto Orgánico de Colombia", conocido como "de la Dictadura", en el cual, fiel a sus propósitos de querer para Colombia el reconocimiento pontificio de la soberanía, incluyó dentro de las disposiciones generales el siguiente artículo:

Artículo 25.- El gobierno sostendrá y protegerá la Religión Católica, Apostólica, Romana, como la religión de los colombianos.

En nombre de Dios, como Supremo legislador del universo, el Congreso Admirable expidió una Constitución en 1830, la cual, aunque no surtió efectos, proclamaba en un título particular, los siguientes principios:

Título II. De la religión colombiana

Artículo 6.- La religión Católica, Apostólica, Romana es la religión de la República.

Artículo 7.- Es un deber del Gobierno, en ejercicio del patronato de la iglesia colombiana, protegerla y no tolerar el culto público de ninguna otra.

Este período grancolombiano y neogranadino, en el cual existieron dos naciones, la primera integrada además por los departamentos de Cundinamarca, Venezuela y Quito, fue fructífero para nuestra nación, pero lento para el establecimiento de las relaciones con la Santa Sede la cual demoró el reconocimiento soberano de las nacientes repúblicas debido a la influencia española en la corte pontificia.

En 1831, el 17 de noviembre, fue expedida la Ley Fundamental de la Nueva Granada, que se constituía en el primer documento de la república que sustituiría a Colombia, la grande; sin embargo, en ella no hubo ninguna mención al carácter religioso de la patria y más bien se dejaría esta materia para que el Congreso, reunido en 1832, al expedir 
una nueva Constitución con fecha $1^{\circ}$ de marzo, manifestase en su proclama inicial lo siguiente:

"Existiendo ya el Estado, preciso era que tuviese una constitución. De otro modo vendrían los granadinos a ser presa de la anarquía o del despotismo. Vuestros representantes, pues, acometieron la empresa de daros esta constitución, como que para ello estaban especialmente autorizados. Os la presentan, seguros de que vuestro buen sentido, vuestro patriotismo y vuestras virtudes os inducirán a cumplirla exacta y puntualmente. En ella se han establecido la separación de los poderes que constituyen el gobierno, la responsabilidad de los funcionarios públicos, la libertad legal de la prensa, y el riguroso deber que tiene la Nueva Granada de proteger la santa religión Católica, Apostólica, Romana, esta religión divina, la única verdadera, precioso origen del bien que heredaron los granadinos de sus padres, que recibieron del cielo en el bautismo, y que por la misericordia del Dios que adoramos, conservaremos todos intacta, pura, $y$ sin mancha. En la constitución, igualmente, se ha procurado fijar la importancia de las provincias del Estado, concediendo a cada una de ellas una cámara que cuide de sus propios intereses, que supervigile sus establecimientos, que fomente su industria, que difunda la ilustración, y que tenga la intervención conveniente en el nombramiento de sus empleados, y de los de la Nueva Granada entera. En adelante ya el centralismo no será el obstáculo de la felicidad de los pueblos, y la prosperidad de cada uno de ellos estará en las manos de sus inmediatos mandatarios. Y ¿cómo habrían vuestros representantes de haber olvidado que la confusión y mezcla de los poderes del gobierno fue la esencia de la devastadora dictadura y el blanco a que se dirigió la más cruel y sangrienta de las usurpaciones? Y ¿cómo habrían de haber omitido rendir pública y solemnemente el homenaje humilde $y$ sincero de su propio corazón hacia esa religión sacrosanta, que fue su exclusivo consuelo en los días de amargura, que hizo sufrir a la patria la tiranía más detestable: ese lazo indisoluble y sagrado que une a todos los granadinos con el cielo, y por cuya conservación inmaculada perderían todos la vida? Y ¿cómo habrían de haber dejado a las provincias sumidas en el abatimiento, degradadas en el orden político, abandonadas a discreción de agentes que no mereciesen su confianza, y separadas hasta cierto punto del gobierno, sin contacto, sin cohesión entre sí, ni con el mismo gobierno? -Estas obligaciones, os lo repiten vuestros representantes, han sido desempeñadas con el mayor celo de su parte." 
Y en su artículo $15^{\circ}$, consagró:

Artículo 15.- Es también un deber del gobierno proteger a los granadinos en el ejercicio de la religión católica, apostólica, romana.

Por fin, el 26 de noviembre de 1835, Su Santidad Gregorio XVI reconoció oficialmente a la Nueva Granada como nación independiente y recibió en calidad de encargado de negocios al doctor Sáenz de Tejada, tras once años de espera. Por su parte, el Vaticano designó a Monseñor Gaetano Baluffi con el carácter de Internuncio Apostólico, el cual presentó sus credenciales al presidente de la república Francisco de Paula Santander el 22 de enero de 1837, estando en funciones hasta el 30 de julio de 1842.

Sin embargo, un grave inconveniente se produciría cuando en 1836 el Congreso Neogranadino le otorgó a los jueces competencia para juzgar a prelados y visitadores eclesiásticos.

La Carta de 1832 estaría vigente hasta 1843, cuando se juzgó necesario reemplazarla por otra que con siguiendo un modelo más liberal, expresase el 8 de mayo, en nombre de Dios Padre, Hijo y Espíritu Santo:

Artículo 15.- Es también un deber del Gobierno proteger a los granadinos en el ejercicio de la Religión Católica, Apostólica, Romana.

Título IV. De la religión de la República

Artículo 16.- La Religión Católica, Apostólica, Romana, es la única cuyo culto sostiene y mantiene la República.

Ruptura radical 1853 a 1888.

En este período fue de buen uso la expresión "el Estado no tiene más actividad que el derecho, y la Iglesia no tiene más campo que la religión". Cada uno estaba por su lado como entidades distintas e insociables, tal y como lo querían hacer ver los liberales radicales del siglo XIX, puesto que en la segunda mitad de este siglo se quiso instaurar un Estado liberal y laico, por un lado y, por el otro un Estado conservador, apoyado por la Iglesia y este partido político.

Luis Javier Ortiz Mesa, sobre ese particular, expresa que "La Iglesia en Colombia tuvo un doble papel, actuó como una entidad polarizadora de la vida política y social, al defender sus fueros y 
participar activamente en la creación de la opinión pública, las elecciones y las guerras civiles y, al tiempo, se constituyó en fuerza civilizadora, al irradiar sus sociabilidades por la geografía nacional, crear instituciones para la educación y la beneficencia, y atender sus campos de misión mediante la <evangelización de salvajes> realizada por comunidades religiosas masculinas y femeninas de inmigrantes europeos y de nacionales, las cuales sustituyeron al Estado, en el 65\% del territorio nacional, entre finales del siglo XIX y las primeras décadas del siglo XX". ${ }^{29}$

Como señalaba Tobón, ${ }^{30}$ en esta época "el fundamental error en que se basa el sistema de separación reside en el perverso modo de entender la libertad de conciencia que para los liberales consiste el deber de proteger cualquier opinión aun errónea, y la facultad de enseñar cada cual lo que le venga en gana, y de adorar a Dios con cualesquiera ritos, aun falsos: el Estado debe permanecer en una posición neutra para defender por igual a todos."

Precisamente San Pío $X$ sobre situaciones como las que vivió Colombia en esta época del siglo XIX, dijo: "Quod maxima afficit injuria Deum, quem sollemniter ejurat, principio declarans rempublicam cujusvis religiones cultus expertem", que quiere decir: "Máxima injuria y rechazo solemne se hace a Dios con el principio que declara a la república libre del culto religioso."

Durante el mandato del general Pedro Alcántara Herrán fue notoria la armonía de trato entre las potestades civil y eclesiástica, la cual se fue deteriorando con las leyes sobre patronato y diezmos dictadas en 1851 por el Congreso, en especial las de mayo 9 y 27, "que suprimía todo rastro de fuero eclesiástico y sometía al poder civil las causas tanto civiles, como criminales de los Ministros sagrados; y la Ley de 27 de mayo que reformó la Ley del Patronato, atribuyendo a los Cabildos parroquiales el nombramiento de los párrocos", ${ }^{31}$ respectivamente.

El general José María Obando había querido desde siempre la separación entre la Iglesia y el estado y lo logró al asumir la presidencia, al obtener del Congreso una Ley del 15 de junio que así lo decretaba.

En nombre de Dios, legislador del Universo, el Congreso expediría el 20 de mayo de 1853 una nueva Constitución que garantizaba a todos

${ }^{29}$ Ortiz Mesa, Luis Javier. La Iglesia católica y la formación del Estadonación en América Latina en el siglo XIX. El caso colombiano. Almanack, Guarulhos \# 6, p. 5 - 25, segundo semestre de 2013: p. 7.

30 Tobón R., Octavio. 1954: p. 64.

${ }^{31}$ Eguren, Juan Antonio, S.J., 1974: pp. 183 y 184. 
los granadinos la profesión libre, pública o privada de la religión que a bien tengan, con tal que no turben la paz pública, no ofendan la sana moral, ni impidan a los otros el ejercicio de su culto, como expresaba el numeral $5^{\circ}$ del artículo $5^{\circ}$, en una época de clara hostilidad religiosa, como ya lo expresamos.

Rápidamente la Carta de 1853 perdió vigencia e incluso fue inaplicada durante la dictadura del general Melo y, entre dar un paso radical al centralismo o abrirse definitivamente a la federación, se optó por este último esquema, cambiando incluso el nombre de República de la Nueva Granada por el de Confederación Granadina, cuya Constitución del 22 de mayo de 1858, bajo la protección de Dios omnipotente, autor y supremo legislador del universo, se refirió así al tema:

Artículo 56.- La Confederación reconoce a todos los habitantes y transeúntes:

10. La profesión libre, pública o privada de cualquier religión; pero no será permitido el ejercicio de actos que turben la paz pública, o que sean calificados de punibles por leyes preexistentes;

Artículo 66.- Ninguna ley de la Confederación ni de los Estados podrá dar a los templos y edificios destinados al culto público de cualquiera religión establecida en el país, ni a los ornamentos y vasos sagrados, otra aplicación distinta de la que hoy tienen, ni gravarlos con ninguna especie de contribuciones. Las propiedades y rentas destinadas al sostenimiento del culto, y las que pertenezcan a comunidades o corporaciones religiosas, gozarán de las mismas garantías que las de los particulares, y no podrán ser ocupadas ni gravadas de una manera distinta de las de éstos.

Ya se avizoraba en estas disposiciones la tragedia a la que sería sometida la Iglesia con el decreto de desamortización de bienes de manos muertas (comprados por hacendados y comerciantes) y la expedición de las disposiciones que permitirían la cuasi - independencia de los ocho estados existentes, al proclamarse el Pacto de Unión del 20 de septiembre de 1861, que disponía:

Artículo 4.- Se consideran como bases invariables de unión entre los Estados:

4. El reconocimiento, en los mismos términos del inciso $1 .^{\circ}$, de los derechos y garantías individuales a todos los habitantes y transeúntes por el territorio de la Unión, a saber: 
a) La profesión libre, pública o privada, de cualquiera religión, siempre que su ejercicio no sea o pueda ser contrario a la moral, a la seguridad o a la tranquilidad pública;

Estas disposiciones precedentes, estarían vigentes mientras se expedía la Carta de 1863, que además de la tuición de cultos, desconoció el nombre de Dios del preámbulo, vulnerando el sentimiento religioso patrio de quienes ahora integraban una nueva nación con el nombre de Estados Unidos de Colombia, para los cuales fue expedida una Constitución el 8 de mayo de ese año.

Artículo 15.- Es base esencial e invariable de la Unión entre los Estados, el reconocimiento y la garantía por parte del Gobierno general y de los Gobiernos de todos y cada uno de los Estados, de los derechos individuales que pertenecen a los habitantes $y$ transeúntes en los Estados Unidos de Colombia, a saber:

16. La profesión libre, pública o privada, de cualquier religión; con tal que no se ejecuten hechos incompatibles con la soberanía nacional, o que tengan por objeto turbar la paz pública.

Artículo 33.- Son elegibles para los puestos públicos del Gobierno general de los Estados Unidos, los colombianos varones mayores de 21 años, o que sean o hayan sido casados; con excepción de los Ministros de cualquier religión.

Bien lo señalaba Eguren, ${ }^{32}$ que entre 1853 y 1878 , lo cual comparto, la Iglesia sufrió muchos atropellos y vejaciones, entre ellas, el que

"Prelados beneméritos con el Legado pontificio a la cabeza, desterrados del país, disueltas las Comunidades religiosas, y sus hijos más prestigiosos sometidos a pruebas humillantes. Con razón diría el Presidente Núñez, en 1885: La tolerancia que muchas veces hemos encomiado, no ha sido en realidad sino una irritante intolerancia."

Después de 1878 y antes de pasar a la etapa concordataria, el padre Eguren, S.J., dice que hubo otro período que va de 1878 a 1887, cuando se firmó un modus vivendi entre el general Sergio Camargo y el cardenal Nina, Secretario de Estado de Su Santidad León XIII, aunque el citado acuerdo no tuvo validez, ni aprobación por parte del Congreso, ya que Núñez esperaba solucionar con él las famosas "Cuestiones

${ }^{32}$ Eguren, Juan Antonio, S.J., 1974: p. 186. 
pendientes", que en últimas no eran más que concretar la ley a sus necesidades, cuales eran anular su matrimonio eclesiástico con Dolores Gallego, para poderse casar canónicamente con Soledad Román, con quien había contraído previamente matrimonio civil en París. Sin embargo, antes de que se pudiera expedir el fallo, doña Dolores falleció en 1889, ante lo cual, las cercanas amistades del Presidente pudieron recibir una tarjeta que decía así: ${ }^{33}$

"Rafael Núñez saluda a usted atentamente y tiene el honor de participarle que ante el altar de San Pedro Claver elevará a la categoría de sacramento, el matrimonio que tiene contraído con doña Soledad Román."

Concordataria 1886 a 1991.

Luego de una cruenta y fratricida guerra que prácticamente duró los 22 años de su vigencia, el movimiento regeneracionista liderado por el cartagenero Rafael Wenceslao Núñez Moledo, propició la reunión de una Convención Nacional de Delegatarios, en razón de a dos por cada Estado de los nueve existentes a esa fecha, para que previa la convocatoria de las 619 municipalidades aprobaran las llamadas "Bases de la Reforma", redactadas por don Miguel Antonio Caro, y pudiesen arreglarse con la Iglesia las "cuestiones pendientes", que dieron lugar a un significativo preámbulo y a estos artículos:

En nombre de Dios, fuente suprema de toda autoridad, los Delegatarios de los Estados Colombianos de Antioquia, Bolívar, Boyacá, Cauca, Cundinamarca, Magdalena, Panamá, Santander y Tolima, reunidos en Consejo Nacional Constituyente; vista la aprobación que impartieron las Municipalidades de Colombia a las bases de Constitución expedidas el día 1. ${ }^{\circ}$ de diciembre de 1885; y con el fin de afianzar la unidad nacional y asegurar los bienes de la justicia, la libertad y la paz, hemos venido en decretar, como decretamos, la siguiente: CONSTITUCIÓN POLÍTICA DE COLOMBIA.

(...)

Artículo 38.- La Religión Católica, Apostólica, Romana, es la de la Nación; los Poderes públicos la protegerán y harán que sea respetada como esencial elemento del orden social. Se entiende que la Iglesia Católica no es ni será oficial, y conservará su independencia.

${ }^{33}$ Eguren, Juan Antonio, S.J., 1974: p. 192. 
Artículo 39.- Nadie será molestado por razón de sus opiniones religiosas, ni compelido por las autoridades a profesar creencias ni a observar prácticas contrarias a su conciencia.

Artículo 40.- Es permitido el ejercicio de todos los cultos que no sean contrarios a la moral cristiana ni a las leyes.

Los actos contrarios a la moral cristiana o subversivos del orden público, que se ejecuten con ocasión o pretexto del ejercicio de un culto, quedan sometidos al derecho común.

Artículo 41.- La educación pública será organizada y dirigida en concordancia con la Religión Católica.

La instrucción primaria costeada con fondos públicos, será gratuita y no obligatoria.

Después de ser sometida a 72 reformas, las cuales dos fueron mediante ley, una por Plebiscito, una por Decreto Legislativo y 68 por Acto Legislativo, el 31 de octubre de 1910 fue expedido el Acto Legislativo 3, que daba a la Constitución el siguiente preámbulo y dejaba intacta la redacción de la codificación inicial, artículos 38 al 41, sobre la materia:

En el nombre de Dios, fuente suprema de toda autoridad, la Asamblea Nacional de Colombia,

La llamada cuestión religiosa, recibió una serie de enmiendas introducidas con el Acto Legislativo 01 de 1936, que expone Vicente Prieto $^{34}$ así:

"En concreto, en virtud del art. 13 del citado Acto Legislativo, el artículo 53 de la Constitución pasó a tener la siguiente redacción: El Estado garantiza la libertad de conciencia. Nadie será molestado por razón de sus convicciones religiosas, ni compelido a profesar creencias ni a observar prácticas contrarias a su conciencia. Se garantiza la libertad de todos los cultos que no sean contrarios a la moral cristiana ni a las Leyes. Los actos contrarios a la moral cristiana o subversivos del orden público que se ejecuten con ocasión o pretexto del ejercicio de un culto, quedan sometidos al derecho común. El Gobierno podrá celebrar con la Santa Sede convenios sujetos a la posterior aprobación del Congreso para

34 Prieto Martínez, Vicente. 1998. El Concordato en la Jurisprudencia Colombiana. Tomo I. 45 Bogotá: Ediciones Universidad de La Sabana. 
regular, sobre bases de recíproca deferencia y mutuo respeto, las relaciones entre el Estado y la Iglesia Católica.

La novedad en relación con la Constitución de 1886, aparece en el reconocimiento expreso por parte del Estado de la garantía de la libertad de conciencia. Al mismo tiempo se garantiza -y no solamente se permite- "la libertad de todos los cultos que no sean contrarios a la moral cristiana ni a las Leyes". Por lo demás, se derogó explícitamente el principio de la confesionalidad de la nación, aunque no el principio de cooperación con la Iglesia Católica (cfr. Inciso cuarto del citado art. 53)".

Por medio del Decreto 0247 del 4 de octubre de 1957, el pueblo de Colombia fue convocado para votar un plebiscito el $1^{\circ}$ de diciembre de ese año, el cual incluía un nuevo preámbulo, que fue redactado así:

"En nombre de Dios, fuente suprema de toda autoridad, y con el fin de afianzarla unidad nacional, una de cuyas bases es el reconocimiento hecho por los partidos políticos de que la Religión Católica, Apostólica y Romana es la de la Nación, y que como tal, los poderes públicos la protegerán y harán que sea respetada como esencial elemento del orden social y para asegurar los bienes de la justicia, la libertad y la paz, el pueblo colombiano, en plebiscito nacional..."

Para Uribe y Lastra, ${ }^{35}$ el preámbulo no convirtió a nuestra nación en un Estado teocrático, sino que allí se expresaba la profunda concepción religiosa de la mayoría del pueblo y agregaron: "Aquí la voluntad soberana no es la de Dios, al menos directamente, sino la de la Nación, pues reunido el pueblo en plebiscito decretó la Ley Fundamental. Es una Constitución democrática, basada en la voluntad popular. En desarrollo de su voluntad soberana, la nación colombiana manifiesta como valores superiores de su orden jurídico la unidad nacional; la religión católica como elemento básico de la unidad nacional; esencial elemento del orden social y base de la justicia, la libertad y la paz."

Además, para los críticos de esta Constitución, debemos señalar que el hecho de que en ella estuviere indicado el reconocimiento especial a la religión Católica como la de la nación, no significa que únicamente se estuviera considerando lo religioso, sino remitiéndose al parecer de quienes votaron el plebiscito: hombres y mujeres para quienes en 1957 la Iglesia era y es factor de unidad y respeto para gran parte de los colombianos.

\footnotetext{
${ }^{35}$ Uribe Blanco, Mauricio y Lastra Jiménez, Álvaro. 1990: p. 40.
} 
Ampliamente reseñada en el acápite precedente, podemos repetir que aquí se da el desarrollo de las fuentes pacticias que configuran parte del Derecho Eclesiástico del Estado, comenzando con el Modus Vivendi firmado en 1880 entre el representante de Colombia, general Sergio Camargo y el del Vaticano, Cardenal Nina, documento no aprobado por el Congreso, lo cual sí ocurriría con el que se suscribiría el 31 de diciembre de 1887 entre el general Joaquín Fernando Vélez y el Cardenal Mariano Rampolla del Tíndaro, que sí obtuvo el aval legislativo con la ley 35 de 1888.

Benéfico para Colombia, pero también para la Iglesia, el Concordato de 1887 hizo que León XIII, en premio a la lealtad y fidelidad de don Joaquín Fernando Vélez con los intereses de su patria, le concediera la Gran Cruz de San Gregorio Magno y la Encomienda de Pío IX, u Orden Piana y, el Cardenal Rampolla del Tíndaro le agregaría a Vélez lo siguiente, que no es más que la explicación de haber sido un tratado generoso y benéfico para los intereses colombianos, nación de tradición y raigambre católica: ${ }^{36}$

"He sido para Colombia negociador generoso y complaciente; y mientras a Usted le erigirán una estatua en Colombia, a mí me lapidarán los Cardenales."

Uribe y Lastra ${ }^{37}$ han dicho sobre esta etapa que "el Derecho Eclesiástico del período histórico que se extendería desde 1887 hasta 1936, se caracterizaría por basarse en el principio de la confesionalidad católica del Estado; por establecer una normativa relativa a la Iglesia Católica con recurso al procedimiento de la legislación concordada; por basar el régimen jurídico de las demás confesiones en criterios fundados, no en el acuerdo de los grupos religiosos interesados sino en planteamientos del tema deducidos del criterio oficial de la Iglesia Católica, que era, por ese entonces, el de la tolerancia."

En 1973 finalmente es suscrito en Bogotá un Concordato, después de varios intentos fallidos por modificarlo, y con él comenzó para el Derecho Eclesiástico una nueva etapa de regulación jurídica del fenómeno religioso, que hizo caer con la Asamblea Constituyente la vieja declaratoria del Preámbulo de 1957 y se pasó a hablar de un nuevo período de aconfesionalidad, que incluyó su refuerzo con las sentencias de la Corte Constitucional, particularmente con la decisión C-027 de 1993, que declaró parcialmente inexequible la Ley 20 de 1974, aprobatoria del Concordato con la Santa Sede.

${ }^{36}$ Eguren, Juan Antonio, S.J., 1974: p. 193.

37 Uribe Blanco, Mauricio y Lastra Jiménez, Álvaro. 1990: p. 25. 
En Colombia, algunos creen que el Concordato es, al menos hoy, inútil cuando no contraproducente, pues ha servido en otros momentos históricos, pero hoy día dada la sensibilidad eclesial y política de los hombres, o son mayores cada día los problemas que las ventajas o no se resuelve nada. La Iglesia justifica con tres motivos el Concordato:

- La salvaguarda y garantía de la libertad en el ejercicio de sus funciones.

- La consecución de una estructura política y un ordenamiento jurídico del Estado de inspiración cristiana.

- La regulación convenida de materias que sean de interés tanto para el Estado como para la Iglesia.

Ese triple objetivo parece que mejor funciona en los Estados Democráticos sin necesidad de tener que recurrir a un Concordato.

Si el Estado es de signo totalitario y no respeta o reconoce a todos los ciudadanos o grupos sociales sus derechos fundamentales, puede el Concordato llegar a tener alguna utilidad y eficacia, pero en cambio, la Iglesia aparecerá como privilegiada, al menos en relación con otros grupos y ciudadanos, cosa que empaña su testimonia y hace difícil su tarea evangélica. En lo referente al Estado Democrático, la doctrina propugnada, peca de idealismo y de excesiva confianza en que los poderes estatales serán siempre fieles y consecuentes con sus propios principios y normas.

En ejercicio de la facultad conferida por el artículo 40 de la Constitución Nacional a los colombianos mayores de 18 años y en ejercicio de su ciudadanía, y apoyados en el numeral 4 del artículo 241 de la Carta, los ciudadanos Carlos Fradique Méndez, Víctor Velásquez Reyes, Israel Morales Portela, Luis Eduardo Corrales, Víctor Manuel Serna, Fabián Gonzalo Marín y Javier Bernardo Torres, demandaron ante la Corte Constitucional la inexequibilidad del Concordato entre la República de Colombia y la Santa Sede, suscrito en Bogotá el 12 de julio de 1973 y, su Ley Aprobatoria, la 20 de 1974.

Para justificar la constitucionalidad de las normas acusadas, se recibieron en la Corte Constitucional escritos de las abogadas Martha Esperanza Rueda Merchán e Idora Astrid Valladares Martínez, apoderadas del Ministerio de Relaciones Exteriores, del abogado Raúl Alejandro Criales Martínez, apoderado del Ministerio de Justicia, del Presidente del Congreso de la República, de los ciudadanos Jorge Humberto Romero Monastoque y Guillermo Moreno García y de los Monseñores Pedro Rubiano Sáenz, Darío Castrillón Hoyos, Victor Manuel López Forero, Jorge Ardila Serrano, Alvaro Raúl Jarro Tobo y Fabio Suescún Mutis, Obispos de distintas Diócesis del país y miembros 
de la Conferencia Episcopal de Colombia, los cuales señalaron entre otras cosas que siendo Colombia parte de la Convención de Viena sobre el derecho de los Tratados, la cual señala que los pactos deben ser cumplidos de buena fé y que una parte no podrá invocar las disposiciones de su derecho interno como justificación del incumplimiento de un tratado, debía entonces el Estado colombiano estarse a lo establecido y la Corte Constitucional respetar el principio del Pacta sunt servanda, ya que la competencia nacional para ejercer el control jurisdiccional de constitucionalidad se pierde después de perfeccionado el tratado-ley; desde ese instante, el acto se sale del ámbito del derecho interno, se "desnacionaliza", se convierte en sello jurídico complejo y completo del compromiso estatal frente a los demás Estados e instituciones internacionales, trasciende al derecho internacional y se torna indesatable por la jurisdicción nacional así ésta sea de constitucionalidad.

Añadían los memorialistas que la ley que aprueba un tratado, es un elemento de un acto jurídico complejo; es la manera como una de las altas partes contratantes manifiesta su consentimiento a las estipulaciones de "un acto sinalagmático internacional"; 38 no establece por sí solo relaciones de derecho y su eficacia depende del consentimiento de la otra nación contratante, si ésta, por su parte, ratifica las cláusulas convenidas por sus negociadores. La ley que aprueba los tratados públicos internacionales, tiene pues para los intervinientes, un carácter especial, ya que el papel asignado al Congreso en materia de tratados, no se asemeja al que desempeña en materia legislativa.

Igualmente, de las citadas defensas se resume que el juzgamiento de las leyes aprobatorias de los tratados públicos internacionales implica el del tratado mismo que aprueban no en su carácter de Convenio Internacional, naturaleza que aún no ostenta, sino como proyecto de tratado o acto de derecho interno, que permanece en el ámbito del derecho público interno, mientras no se agote un proceso de perfeccionamiento, expresión unilateral de un consentimiento, así mismo modificable unilateralmente, de manera directa o indirecta, o por consecuencia de una sentencia judicial.

Así mismo, dentro del término constitucional, se recibió la Vista Fiscal, en la cual el Jefe del Ministerio Público expresó que existen normas internacionales de jus cogens inderogables por la voluntad de los Estados y que no permiten acuerdo en contrario en vista de los derechos que protegen, pero para él, la Constitución de 1991 elevó a rango supraconstitucional los Tratados y Convenios Internacionales ratificados

38 CORTE CONSTITUCIONAL COLOMBIANA, Sentencia C-027 de 1993, Intervención del Apoderado del Ministerio de Justicia y del Derecho. 
por el Congreso y que reconocen derechos humanos, porque prevalecen en el orden interno y, el Concordato viola y desconoce muchas normas del jus cogens como la libertad religiosa, de igualdad de derechos en cuanto al matrimonio, durante éste y en caso de disolución del vínculo; la libertad de enseñanza, el respeto a la autonomía y derechos y libertades de los indígenas y el derecho a la educación.

Y ya en lo tocante a las consideraciones de la Corte Constitucional, la Corporación realizó un detallado análisis de la tesis que sobre competencia rigen al control jurisdiccional de constitucionalidad, manifestando que:

"SÉPTIMA. - Nuestra Constitución no reconoce la supremacía de los tratados internacionales sobre la Constitución Política. Por tanto, la Carta no autoriza a su guardiana a abstenerse de pronunciar la inexequibilidad de un tratado que aún perfeccionado, viola los postulados fundamentales que estructuran la organización jurídico-política e ideológica del Estado colombiano.

OCTAVA.- Los presupuestos del Estado de Derecho y su esquema de respeto a la supremacía de la Constitución como símbolo máximo de jerarquía jurídica e ideológica, no han sido ni superados, ni modificados; por tanto, se impone mantener la plena vigencia de sus postulados, sometiendo a control los tratados públicos perfeccionados que vulneren sus principios estructurales.

NOVENA.- En el caso de que un tratado internacional, por razón de una violación manifiesta de la competencia atribuida al órgano que lo celebra, causa la trasgresión de una norma fundamental de nuestra Constitución Política, el pronunciamiento de la Corte sobre su inexequibilidad es imperativo porque frente al Derecho Internacional es el órgano a quien la norma fundamental de Derecho Interno, la Constitución, le ha atribuído competencia válida de convalidación de un acto que atenta contra él y que precisamente se busca preservar, y porque frente al derecho Interno es la guardiana de la integridad de la Constitución." ${ }^{39}$

La sentencia C-027 de 1993, también establece que desde la iniciación de labores de la Corte Constitucional (que se instaló el 17 de febrero de 1992 y pronunció su primera Sentencia T-001 el 3 de abril de 1992), ha sido ésta consciente de que su mejor contribución a la paz colombiana es hacer realidad los fines esenciales del Estado Social de Derecho en su conjunto, entre los cuales ocupa lugar preeminente la efectividad de los principios, derechos y deberes consagrados en la

39 CORTE CONSTITUCIONAL COLOMBIANA, Sentencia C-027 de 1993, Magistrado Ponente: Simón Rodríguez Rodríguez. 
Carta, además de que el control jurisdiccional de constitucionalidad confiado por ella a este Alto Tribunal, apunta a ese fin, ante lo cual, mal podría plantearse una contradicción con los postulados del derecho internacional de los derechos humanos y el derecho internacional humanitario, que constituya su razón de ser. Además, se debe tener en cuenta que el ordenamiento jurídico internacional no considera que los vínculos jurídicos considerados en virtud de un tratado, sean indesatables a perpetuidad.

Más tarde, el Presidente de la Corte Constitucional, en nombre de sus compañeros de Sala, expresó resumidadamente lo consignado en la sentencia C-027 de 1993 (Considerada por muchos como la sentencia más larga y confusa de la Corte Constitucional), decisión de la cual únicamente se apartó del parecer de la mayoría con Salvamento de Voto, el Magistrado José Gregorio Hernández Galindo quien consideró que, según la Carta de 1991, lejos de ampliarse, se restringió la competencia jurisdiccional para conocer sobre demandas contra leyes aprobatorias de los tratados públicos internacionales que ya hubieren sido ratificados por Colombia y, por tanto, en cuanto a ellos existe ya un compromiso de Derecho Internacional, que los sustrae de cualquier forma de ruptura unilateral de los compromisos contraídos, por decisión de una autoridad interna.

Dicha Corte Constitucional se ha hecho una pregunta, ${ }^{40} i$ cuál es el sentido que debe darse al sometimiento de los jueces al imperio de la ley, y a su autonomía para interpretar y aplicar el ordenamiento jurídico? Para responder a dicha pregunta, según la Corte, se debe tener en cuenta, a su vez, que: (i) el artículo 113 de la Carta establece que los diversos órganos del Estado tienen funciones separadas pero colaboran armónicamente; (ii) que están constitucionalmente encaminados a garantizar la efectividad de los principios, derechos y deberes consagrados en la Constitución y a asegurar la vigencia de un orden justo; (iii) que la Constitución garantiza la prevalencia del derecho sustancial y; (iv) que el principio de igualdad consagrado en el preámbulo de la Carta, en armonía con las diversas manifestaciones constitucionales de la igualdad -como derechotienen como presupuestos la igualdad frente a la ley, y la igualdad de protección y trato por parte de las autoridades del Estado (art. 13).

La creciente implantación en numerosos países del continente americano de Iglesias y confesiones distintas a la Católica, está replanteando el sistema de Derecho Eclesiástico vigente en los mismos y en nuestro caso particular, en Colombia. Con la Ley Estatutaria de 1994

40 CORTE CONSTITUCIONAL COLOMBIANA. Sentencia C-836 de 2001, Magistrado Ponente: Dr. Rodrigo Escobar Gil. 
que reguló el tema del Derecho Eclesiástico del Estado colombiano, dispuso que el Poder Público esté encargado de proteger a las personas en sus creencias, así como a las Iglesias y confesiones religiosas y facilita la participación de éstas y aquéllas en la consecución del bien común. De igual manera, el artículo $2^{\circ}$ de la Ley dice que el Estado ha de mantener relaciones armónicas y de común entendimiento con las Iglesias y confesiones religiosas existentes en la sociedad colombiana, ya que reconoce la diversidad de las creencias religiosas, las cuales no constituirán motivo de desigualdad o discriminación ante la ley que anulen o restrinjan el reconocimiento o ejercicio de los derechos fundamentales y de acuerdo con las normas constitucionales, todas las confesiones religiosas e Iglesias son igualmente libres ante la Ley.

La última actuación concordataria entre la República de Colombia y la Santa Sede se produjo en 1992, con el llamado Concordato SanínRomeo, que dos décadas más tarde, aún no ha sido llevado por el Gobierno al Congreso de la República para que inicie su trámite de aprobación y posterior control por parte de la Corte Constitucional.

Aconfesional 1991, actual.

Fruto de una Asamblea Nacional Constituyente, el 4 de julio de 1991 fue expedida la Constitución actualmente vigente, que retomó la protección de Dios en su preámbulo y adicionalmente destinó un artículo a la materia religiosa, que fue desarrollado posteriormente a través de una ley estatutaria. Se pasó de la fórmula latina Religio Republicae Colombianae, que reconocía a la religión Católica, Apostólica y Romana como la de la nación, a un período que se enmarca en el que corresponde a la ruptura con el sentimiento profundamente católico del país, lo que había sido reforzado en su momento con más de cuatro millones de votantes, hombres y mujeres (cuando ellas por primera vez ejercieron el sufragio), quienes en 1957 ratificarían un Plebiscito modificatorio de la Constitución, y dentro de él un significativo preámbulo para la Carta. Sin embargo, por no ser el desarrollo de este artículo precisar los acontecimientos que rodearon este tema.

Baste con recordar que años más tarde, gestándose una nueva Carta, el doctor Alberto Zalamea Costa, ponente del preámbulo de la nueva Constitución, expresó en las discusiones ante la Asamblea Nacional Constituyente de 1991, expresó que después de largas y constructivas deliberaciones "invocamos la protección de Dios (sin pretender asumir su vocería, pero recordándolo, sí, como fundamento de la dignidad humana y fuente de vida y autoridad para el bien común)". ${ }^{41}$

41 Lleras de la Fuente, Carlos y Tangarife Torres, Marcel. 1996. Constitución Política de Colombia. Origen, Evolución y Vigencia. Tomo I, 79 
Ese preámbulo permitió entonces pasar a hablar de una laicidad en el Estado colombiano, que requiere defender la política de la intromisión de la religión, pero también la religión de la intromisión de la política, situación que se ha visto en las últimas dos décadas de la historia colombiana, cuando de acuerdo con los intereses en la política participativa de algunas iglesias cristianas no católicas, el Gobierno ha regulado materias de la Ley Estatutaria de la Libertad Religiosa, expedida en 1994, con disposiciones hechas a la medida, como el Acuerdo de Derecho público Interno, que regula las relaciones entre el Estado y 17 Iglesias no católicas en materia del vínculo matrimonial, asistencia religiosa a reclusos, días de descanso y presencia de pastores no católicos en condiciones de igualdad (no de equidad) en guarniciones militares y en centros educativos y hospitalarios.

\section{CONCLUSIONES}

Hemos abarcado aquí un período muy controvertido y controversial de la historia constitucional colombiana, cuyo centro principal, en el orden nacional y provincial, fue la condición de nación sujeta a la Iglesia, cuya herencia y sometimiento, a través de los españoles protagonistas de la conquista y luego del establecimiento del régimen colonial, no fue, para muchos, el mejor comienzo para una Nación que entraba en contradicciones ideológicas como las que se vivieron en 1863 cuando Dios fue excluido del preámbulo constitucional.

Sin embargo, aunque no siempre fue así, el pueblo como titular de la soberanía y, el constituyente de los siglos XIX y XX, consideraron a Dios, ese Ser Supremo, como la fuente de la cual ha emanado la autoridad y la estabilidad de una nación en la cual, el dogma constitucional ha sido el de la religión católica, apostólica y romana, como la única y verdadera religión del Estado.

\section{BIBLIOGRAFÍA}

Adame Goddard, Jorge. 1992. "Las Reformas Constitucionales en materia de libertad religiosa”. Ars luris, $7: 1$ - 3.

Del Giudice, Vincenzo. 1955. Nociones de Derecho Canónico. Traducción y notas de Pedro Lombardía. 333, Pamplona: Publicaciones del Estudio General de Navarra.

Bogotá: Ediciones Rosaristas, Pontificia Universidad Javeriana y Biblioteca Jurídica Diké. 
De la Hera, Alberto: 1992. El gobierno de la Iglesia indiana, en: Sánchez Bella, Ismael, De la Hera Alberto, Díaz Remetería, Carlos. Historia del Derecho Indiano. Madrid, Mapfre.

Eguren, Juan Antonio, S.J. 1974. Derecho Concordatario Colombiano. 166, Bogotá: Librería Stella.

García, Julio César. 1972. Los Primitivos. 14ª edición, 199, Bogotá: Editorial Voluntad.

http://www.cervantesvirtual.com/servlet/SirveObras/891451732112 14929532457/p0000001.htm\#l 0, consultada el $1^{\circ}$ de agosto de 2013.

Lleras de la Fuente, Carlos y Tangarife Torres, Marcel. 1996. Constitución Política de Colombia. Origen, Evolución y Vigencia. Tomo I, 79 Bogotá: Ediciones Rosaristas, Pontificia Universidad Javeriana y Biblioteca Jurídica Diké.

Lombardía, Pedro. 1980. Derecho Eclesiástico del Estado Español. 25, Pamplona: EUNSA.

Lombardía, Pedro. 1983. Derecho Eclesiástico del Estado español. Segunda edición, 28, Pamplona: Eunsa.

Olano García, Hernán Alejandro. 2006. La Constitución Monárquica de Cundinamarca. Bogotá: Colección Portable, Academia Colombiana de Jurisprudencia.

Olano García, Hernán Alejandro. 2010. El Acta de Confederación de las Provincias Unidas de la Nueva Granada. En: Vidal Perdomo, Jaime (Compilador). (2010). Historia constitucional de Colombia - Siglo XIX. Tomo I. Bogotá, D. C., Ediciones de la Academia Colombiana de Jurisprudencia, pp. 29-42.

Olano García, Hernán Alejandro. 2013. La Constitución del Estado de Cartagena de Indias. Bogotá: Colección Portable de la Academia Colombiana de Jurisprudencia.

Olano García, Hernán Alejandro. Bicentenario de la Constitución de Tunja. En: Zambrano Cetina, William (Compilador). (2011). Las Constituciones de la Primera República. Memorias del Coloquio Conmemorativo del Bicentenario de la Constitución de Tunja. Ediciones de la Academia Colombiana de Jurisprudencia, Bogotá, D.C. 
Olano García, Hernán Alejandro. La Constitución de Antioquia de 1812. 2012. Bogotá: Ediciones de la Academia Colombiana de Jurisprudencia, Colección Portable.

Ortiz Mesa, Luis Javier. La Iglesia católica y la formación del Estado-nación en América Latina en el siglo XIX. El caso colombiano. Almanack, Guarulhos \# 6, p. 5 - 25, segundo semestre de 2013.

Ots Capdequí, José María. 1932: La Iglesia en Indias. Aportaciones para el estudio de la Iglesia en la América española durante el período colonial.

Pombo, Manuel Antonio y Guerra, José Joaquín. 1986. Constituciones de Colombia. Tomo I, 4 ed. Bogotá: Biblioteca del Banco Popular. pp. $300-301$

Prieto Martínez, Vicente. 1998. El Concordato en la Jurisprudencia Colombiana. Tomo I. 45 Bogotá: Ediciones Universidad de La Sabana.

Prieto, Vicente. 2005. Relaciones Iglesia-Estado. La perspectiva del Derecho Canónico. 9, Salamanca: Publicaciones de la Universidad Pontificia de Salamanca.

Saldaña, Javier. 1999. "Derecho y principio de libertad religiosa. Un breve análisis de la actitud promotora del Estado frente al hecho religioso". Boletín Mexicano de Derecho Comparado, 95: 588.

Saldaña, Javier. 2004. "Derecho y Religión”. ARS IURIS, 103: 457.

Tobón R., Octavio. 1954. Compendio de Derecho Público Eclesiástico. 9 Bogotá: Temis.

Uribe Blanco, Mauricio y Lastra Jiménez, Álvaro. 1990. Derecho Eclesiástico del Estado Colombiano. Fundamentos. 12 Bogotá: Universidad de La Sabana.

Vásquez García-Peñuela, José María. 1994. "El objeto del Derecho Eclesiástico y las Confesiones Religiosas”. Ius Canonicum, 67: 280. 